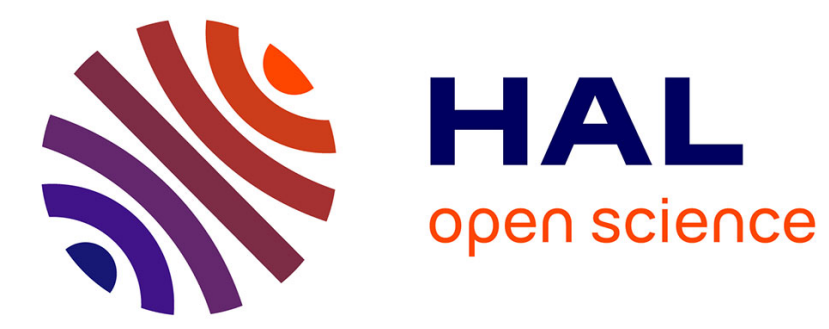

\title{
Intersex: some (legal-)historical background
}

Alain Wijffels

\section{To cite this version:}

Alain Wijffels. Intersex: some (legal-)historical background. [Jens M. Scherpe, Anatol Dutta, Tobias Helms (eds.)] The Legal Status of Intersex Persons (181-200), 2018. hal-03328349

\section{HAL Id: hal-03328349 https://hal.science/hal-03328349}

Submitted on 30 Aug 2021

HAL is a multi-disciplinary open access archive for the deposit and dissemination of scientific research documents, whether they are published or not. The documents may come from teaching and research institutions in France or abroad, or from public or private research centers.
L'archive ouverte pluridisciplinaire HAL, est destinée au dépôt et à la diffusion de documents scientifiques de niveau recherche, publiés ou non, émanant des établissements d'enseignement et de recherche français ou étrangers, des laboratoires publics ou privés. 
The publication of this book was supported by

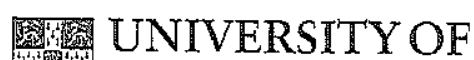

CAMBRIDGE

\section{CFL}
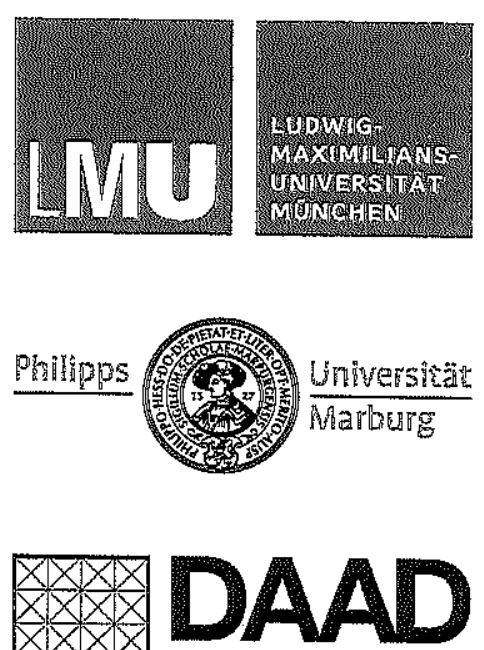

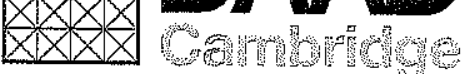

THE LEGAL STATUS OF INTERSEX PERSONS

\author{
Edited by \\ Jens M. SCHERPE \\ Anatol DUTTA \\ Tobias Helms
}

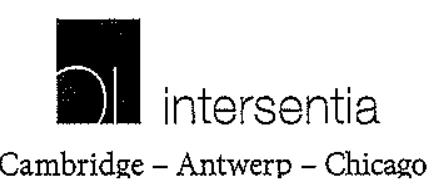


the Mishna in shaping the thought of the Talmud, and secondiy, for thinking of the Talmud's continuous influence. Similar processes to those described by Halbertal in the middle ages occurred law. Through the Talmudic deliberations, the Mishnah shifted from being a normative canon, a text that intended to dictate the law, to being a formative conover, this new status is achieved through a process by which Mishnaic legal perspectives and categories gain new weight, and shape rabbinic acts as well s thought, and create a new reality. In a more recent publication Halbertal put forth the idea that the rise of halakhic discourse was a revolution that emerged through the canonisation of the Mishnah. ${ }^{38}$ The halakhic revolution includes the wider application of the thick, dense, high-resolution and detailed mode of legal discourse. What we have tried to show here is one stage of this revolution in which the categories that were used in the Tannaitic legal discourse became prisms through which reality was understood in later sources, and to point to the mechanisms through which legal categories morph into an essential description of reality. In other words, to show how the normative becomes formative.

\section{INTERSEX: SOME (LEGAL-)HISTORICAL BACKGROUND}

\author{
Alain WIJFFELS
}

1. The Western Cultural Tradition: The 'Hermaphrodite' as a Topos Drawn and Adapted from the Ancient Classical Culture. . ............. 181

2. The Western Legal Tradition: Intersex Challenged and (Re-)Affurmed ... 187

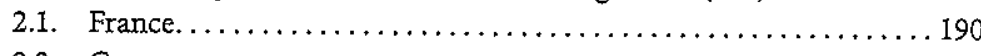

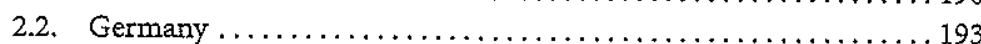

3. An Age of Change (Late Twentieth Century and Early Twenty-First Century)

Until the eighteenth century, the legal approach to 'hermaphrodites', although it presented distinctive features, was influenced by ancient classical texts and by post-classical literature and scholarship. The latter were in turn more or less informed by the ancient sources, but often also reprocessing those sources for contemporary political or social purposes. Both canon law and secular law were also influenced by Christian religious beliefs and doctrines, which to some extent affected the broader popular culture and attitudes to sexuality and gender issues. As those scholarly and popular approaches sometimes intertwined with legal (in particular, forensic) discussions of intersex cases, a brief introductory reference to some aspects of that broader cultural context may be useful. Another necessary contextualisation (which, however, can only be mentioned peripherally in this introductory contribution) is the interaction between medical science and law on this issue.

1. THE WESTERN CULTURAL TRADITION:

THE 'HERMAPHRODITE’ AS A TOPOS DRAWN

AND ADAPTED FROM THE ANCIENT

CLASSICAL CULTURE

Among the non-legal sources which have affected legal literature and thinking on transsexuality, intersexuality, sexual orientations, and gender issues in 
general, the Greek-Roman mythology - as witnessed already by the continuous use of the word 'hermaphrodite' as a term of art in legal authorities until the in which contributed to maintaining the notion that intersexuality occurred, even if it was perceived as a challenge to the natural and social order.

In his Pro populo anglicano defensio (1651), Milton countered the attacks by the French author Claude Saumaise against the English regicides. In the preface, Milton included a pun on Saumaise's Latinised name (Salmasius), comparing him with the nymph Salmacis, who caused the metamorphosis of Hermaphrodite, and associating his opponent with 'effeminate minds', 'emasculating' generous minds, and reduced by the weakness of this argument to a "half-man." Here we have an example of the mythological reference used in a polemical political text, and using the reference to Hermaphrodite in a pejorative, denigrating, sense.

A long and fairly abundant literary tradition from Antiquity to early-modern times documents both empirical and ideational narratives on trans- and intersexuality, in which synchronic or diachronic hermaphrodism is a recurrent theme. That secular literature includes both scientific texts (such as Pliny's accounts) and literary fiction (such as Ovid's Metamorphoses based on mythology), where archetypes of hermaphrodite and transsexual figures appear: Hermaphroditus himself (born from Hermes and Aphrodite), but also Caenis/ Caeneus (becoming a man after having been raped as a woman by Neptune), or Caeneus (becoming a man after having been raped as a woman by Neptune),

Together with classical Antiquity, Christianity has long been one of the pillars on which Western culture rested. Beyond religion and theology, Christianity has for centuries determined the codes of public governance, art and social norms. In the Christian tradition, gender issues have also been a notoriously vexed topic of debate until the present day. In the Roman Catholic Church, the importance of sexuality and the role of women have mostly been at the same time sublimated and repressed. Even so, it should be remembered that, from the outset, as the Epistle to the Galatians emphasised in vivid terms, the transcendent vision offered by Christ's message implied an emancipation from any discriminatory status by reason of one's race, social status or gender. In the kingdom of heaven, there is 'neither male nor female.'

In the sphere of more popular devotion, the account of the martyrdom of Saint Perpetua is an exceptional document which continues to attract the

I[onnnss] Mirton, pro populo anglicano defensio Contra Claudii Anonymi, alias Salmasit, Defensionem Regiam. [Editio emendation, Londini, Typis Du Gardianis, 1651], Praefatio, p. 10.

2 Galatians 3:28. An important doctrinal text in the Western Christian tradition was St. Augustine, De civitate Dei, XVI.8. In early-modern times, the saying "The soul has no ghender' was sometimes attributed to Queen Christina of Sweden. attention of early-Christian scholarship. ${ }^{3}$ Perpetua, a well-born North-African woman and young mother, became a Christian martyr when she was put to death with five other fellow Christians, including her slave and friend Felicity, who was pregnant, in the amphitheatre at Carthage. Felicity and Perpetua were proclaimed saints and their names were included in the Canon of the Mass, ensuring a lasting fame among Roman-Catholics until modern times. The account of Perpetua's last days, attributed to herself, is a deeply personal record of her anxieties as a mother about her new-born baby, from whom she was separated, and of her subconscious representations featured in a sequence of four dreams. In her fourth and last dream, she is being led to the amphitheatre. Entering the arena, where she expects to confront wild beasts, she is surprised that she will have to fight a different adversary:

Instead an Egyptian came out as my opponent, hideous to look at, along with his assistants. He was the one who was going to fight me. Some handsome young men came to my side as well, to assist and support me. And I was stripped naked and became masculine, and my assistarts started rubbing me down with oil the way they do before an athletic contest...

A spectacular fight between Perpetua and the Egyptian ensues, from which Perpetua comes out as the winner. Perpetua is given the prize, a branch with golden apples. By then, she must have metamorphosed into a woman again, for when the referee hands over the award, he kisses her and says: 'Peace be with you, daughter'.

This passage has been interpreted in various ways. Perhaps the most convincing line of interpretation, taking into account the text of the passion in its entirety and against the background of classical narratives and culture in general, is to recognise in Perpetua's account a strong self-awareness of her femininity, both physical and social, which, however, does not preclude, in her determination to die for her faith, a capacity to adopt intergender features.

Medieval and Renaissance literature and arts also offer a wide range of philosophical, scientific and literary examples in which trans- and intersexuality themes are more or less explicitly being explored. ${ }^{4}$ It was a tradition which has cast a long shadow over the concepts and policies on sexuality in Western history until modern times. Alain de Lille's Complaint of nature, for instance, assimilates with hermaphrodism a venereal degeneration of Nature's precepts,

T.J. Hefregnan, The passion of Perpetua and Felicity, Oxford University Press; New York 2012; J.N. BREMMRER AND M. FORMISANO (eds.), Perpetua's passions: multidisciplinary approaches to the Passio Perpetuae et Felicitatis, Oxford University Press, Oxford 2012.

4. Several examples (some of which will be referred to hereafter) are to be found in the essays collected by M. CLOSson (ed.), L' Hermaphrodisme de la Renaissance aux Lumierres Chassigues Garnier, Paris 2013. 
a discourse aimed primarily at condemning non-reproductive sexual behaviour, in particular male homosexuality. ${ }^{5} \mathrm{~A}$ more positive notion of hermaphrodism can be found in a different tradition, such as the philosophical alchemism of Clovis Hesteau de Nuysement, in his Visions hermétiques, poems in defence of alchemy. The author reverts to the concept of the world as a living creature, 'male and female throughout, and joined by mutual love and union of its limbs', a cosmological vision which permeates a great part of his intergender-inspired alchemy. ${ }^{6}$ In the visual arts, the intergender theme was occasionally represented by copying artworks from Antiquity, or by imagining fictional representations which often represented more or less 'monstrous' creatures, or representations offering an echo or reinterpretation of ancient mythology.7 In Jacobean England, hermaphrodites were not only a notion contemporaries were familiar with through legal authorities and testimonies from classical Antiquity. Representations of trans- and intersexuality were also instrumentalised in political polemical writings, such as the famous tracts of 1620 on the 'he-woman' (hic mulier) and the 'she-man' (haec vir), possibly also a criticism levied against allegations of unconventional sexual behaviour among members of the royal court. ${ }^{8}$ In France also, trans- and intersexuality were forms for expressing critical political opinions. In 1605, an anonymous pamphlet (later attributed to Artus Thomas, Lord of Embry) was published under the title (in French) The Newly Discovered Island of the Hermaphrodites ${ }^{9}-$ which inspired

D. RoIIo, Kiss my relics - Hermaphroditic fictions of the Middle Ages, The University of Chicago Press, Chicago and London 2011, pp. 77-142, on Alain de Lille's De planctu Naturae. K.P. LONG, Hermaphrodites in Renaissance Europe, Ashgate, Aldershot 2006, pp. 137-162. Nuysement was a courtier close to the French king Henry III.

To quote but one (albeit particularly relevant in art history) work among innumerous To quote but one (albet partionarosis of Hermaphrodite and the Nymph Salmacis (1517), examples: Jan Gossacts Mersart: A Metamorphosis in H. CAuditi The Virago, Hermaphrodite, and jan 13.

Netherlandist Art (2006) Kaleddocte Three Pamphlets on the Jacobean Ant Introduction by Barbara . Baines, Scholars Facsimiles and Reprints, Delmar, New York 1978 including Hic Mulier: Or, The Man-Woman: Being a Medicine to cure the Coltish Disease of the Staggers in the Masculine-Feminines of our Times (London, printed for I.1. and are to be sold at Christ Church gate. 1620]; Haec Vir: Or, The Womanish-Man: Being an Answere to a late Booke intituled Hic-Mulier. Exprest in a briefe Dialogue between Haec-Vir the Womanish-Man and Fic-Mulier the Man-Woman [London printed for I.T. and are to be sold at Christ Church gate. 1620].

Modern edition: Lissle des Hermaphrodites, ed. C.-G. DuBors, Droz, Genève 1996. The pamphlet enjoyed more than an ephemeral appeal and was reprinted in the following century - prompting at the time the Roman-Catholic authorities to include it in their index of prohibited works. The 1724 edition reproduced the image already appearing in the 1605 original imprint, showing a figure with male and female characteristics and attributes, but claiming in a few accompanying verses to be neither male nor female - though enjoying the pleasures of both genders. The verses highlight one of the core values attributed to the inhabitants of the island: the purely hedonistic quest for pleasure and self-gratification as the highes goal of all The subtitle of the book, added in the 1724 edition, gives away that the following year a polemical pamphlet Lanti-hermaphrodite. 10 The Island of the Hermaphrodites is inspired by the format and register of other earlymodern political tracts. The story of Europeans being washed up after a shipwreck on the shores of an unknown (and in this case, floating) island with its distinctive people, culture and polity, is of course partly reminiscent of More's Utopia. Artus Thomas' pamphlet seems, however, to have targeted a more specific political context, and is usually understood to entail a barely disguised criticism and satire of King Henry III and his court. The fiction of the hermaphrodites in the pamphlet is rather a stylistic and rhetorical device aimed at reinforcing a negative association between the utopian society and the target of the author's criticism, partly by mocking the perceived or alleged effeminate and homosexual tendencies of Henry III's court. Conventional gender roles or gender identities are not being challenged, the caricature of intersexuality implies, on the contrary, an attachment to stereotyped gender definitions.

Mainstream eighteenth-century views did not necessarily converge. This can be illustrated by comparing the entries on 'hermaphrodites' in two general works of reference, the German Zedler Lexicon and the French Encyclopedie. The German entry (in the 1732 edition) ${ }^{11}$ states that the existence of hermaphrodistic features is accepted as a fact by the medical profession ('eine ausgemachte Sache'). Hermaphroditism is also extensively documented in the animal and botanical species. The entry also refers to the legal principles, which, it says, will categorise an incividual with hermaphrodistic features according to the prevailing sexual characteristics; if the features are in balance, the individual will make a choice, because (here a moral element creeps in) it would be monstrous to use both sexes; the individual must pledge under oath not to come back on that choice. While still a child, such a person will be deemed to be masculine. When the person intends to marry, a commission of physicians and midwives will have to determine the sex. The entry also considers the vexed issue of a

a spoof compilation of the island's legal system is instrumental in articulating a criticism of a certain political establishment and culture. As in other early-modern political essays, this work purports to describe 'the usages, customs and statutes of the inhabitants' of the island. One might expect that hermaphrodites would not be hampered by sex discrimination. However, the island's society remains steeped in the inequalities to be found in other, more However, the island's society remains steeped in the inequalities to be found in other, more
conventional societies, and occasionally, a gender-biased note slips into the description of the island's survey, for example when the author lampoons the frivolity of fashion, useful, he says, to converse with ladies; or when he describes the discipline in military barracks, which will L have to provide for a multitude of loose women.

As the full title shows, this, too, purported to deal with issues of public governance: Lantihermaphrodite ou le secret, tant désiré de beaucoup, de ladvis proposé au Roy pour reparer par un bel ordre, et legitime moyen aussi facilement, qu' insensiblement, tous les désordres, impiétes, iniustices, abus, meschancetez, \& corruptions qui sont en ce Royaume... [A Paris, Par Iean Berjon, 1606].

11 Grosses vollständiges Universal Lexicon Aller Wissenschaften und Künste ... [Halle und Leipzig Verlegts Johann Heinrich Zedler, 1732-], T. XII (1735), s.v. Hermaphroditus, col. 1723-1725, 
hermaphrodite who after the death of the wife or husband, wants to marry a person of the opposite sex. The author of the entry expresses the opinion that although such a course of action may be warranted by 'natural reason', public policy considerations would prevent it.

By contrast, the principal entry in the Encyclopédie states that hermaphrodism does not exist. ${ }^{12}$ Ambiguous appearances may have confused popular and unenlightened beliefs, but the author is in no doubt that proper medical inspection of any individual will establish either that such individual may be classified as a woman or a man, either as having neither sex sufficiently developed. It would therefore seem that the concept of hermaphrodism was reduced to an anatomical utrumque, not including an individual appearing to be neutrum. In a Supplement volume, ${ }^{13}$ the same thesis of the non-existence of 'true hermaphrodites' is repeated, but the register of the entry follows entirely a scientific and medical approach (by the standards of the time), including detailed anatomical and clinical observation (when possible by a group of physicians) ${ }^{14}$ and when availabie including the report of a post-mortem dissection. That register is also expressed in some of the illustrations to which the entry refers and which highlight graphically the progress of anatomical descriptions of the internal side of the reproductive organs..$^{15}$

The detailed scientific graphic depiction of the human body made much progress during the eighteenth century. William Cheselden's work with plates became an important work of reference, reaching a 13th edition by 1792 . It included foures on human hermaphroditism, and in particular of an individual from Angola who had been brought to London. ${ }^{16}$ The case, illustrated with Cheselden's plates, became a well-known reference in eighteenth-century Europe in discussions on hermaphrodites. Voltaire, for example, expressed hi scepticism about the existence of hermaphrodites, without stating an outright

12 Encyclopédie, ou dictionnaire raisonné des sciences, des arts et des métiers ... [A Paris, Chez Encyer. 1751-1, T. 8, s.v. 'Hermaphrodite', pp. 165-167.

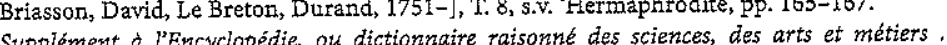
Supplément da l'Encyclopédie, ou dictionnaire raisonne des sciences, des arts

14 See below the references to the inquiry in 1802 into the gender of Jacqueline Foroni. An See below the references to the inquiry in 1802 in to the gender of facqueline Foroni. An officially sanctioned inquiry was carried out by a commission according to the standards of officialdom and scientific rigour expected by the enlightened agents of the French Republic. The result was that Foroni was a man. Foroni's own wish and expectation to be recognised (as she had always been) as a woman, and ever her inclination towards men, was dismissed by the officials as an effect of a misguided education and social patterns. This case may be seen as a strong example of the effects of the same ideology expressed in the Encyclopedie, where assertions of intersex were rejected as expressions of non-rational opinions and superstitions.

15 Suite du recueil de planches, sur les sciences, les arts libéraux, et les arts méchaniques, avec leur explication [A Paris, Chez Pancoucke, Stoupe, Brunet; A Annsterdam, Chez M.M. Rey, 1777], p. 14 and 3 full-page plates s.v. 'Hermaphrodite' (Histoire naturelle).

16 W[ruliam] Chrpspiden, The Anatomy of the Human Body [I have used: The VIIth ed., London Printed for C. Hitch \&\& R. Dodsley 1750], p. 314, Plate 33 . denial. Like many contemporaries, he believed the occurrence might more likely be observed in southern regions. Hence, he referred to the Angolan individual, referring explicitly to Cheselden's work and plates, and also to communications with the author. Voltaire admitted that the existence of full human hermaphrodites was possible. 'Je n'affirme rien. ... Je doute.17

\section{THE WESTERN LEGAL TRADITION: INTERSEX CHALLENGED AND (RE-)AFFIRMED}

A handful of fragments from classical Roman jurists which deal explicitly with an issue involving a 'hermaphrodite' (the term of art used in the legal texts) were incorporated in the Digest by Emperor Justinian. ${ }^{18}$ From the Second Middle Ages onwards (i.e. from the eleventh to the fifteenth century), the Digest was the main compilation used in the education of students in civil law all over Western Europe until the end of the eighteenth century. The texts of Roman law were also acknowledged and used as legal authorities in legal practice throughout Europe (although in England, only in marginal civil, including ecclesiastical, law courts). For centuries, those fragments therefore ensured that, however peripheral, a notion of intersexuality retained a presence in legal literature.

A complex example of late-medieval doctrine on the subject is a legal opinion (consilium) by Baldus de Ubaldis on a question of feudal inheritance. A young person described as a son displayed imperfect genital organs, and his father's will provided that he would not inherit a share of the feudal estate if, by the time he reached the age of 28 , his male sexuality had not been ascertained. Baldus' opinion reviews several doctrines, including that of the canonist Henricus de Segusio, according to whom, in the case of doubt, the decision was to be left to the person in question, who, in conscience, was better placed to determine her or his sexuality. Baldus, however, perhaps considering that this was not a case where a doubt was at stake, argued that since the son could not qualify as an heir, he was barred from the feudal inheritance. The argument is nevertheless

17 F[RANÇOTS] RAVIRZ, 'Voltaire ou l'hermaphrodite en question(s)', in L'Hermaphrodisme de la Renaissance aux Lumières, above, n. 4, pp. 279-303.

18 Perhaps the most comprehensive legal-historical survey on intersexuality remain A. WACKB, "Vom Hermaphroditen zum Transsexuellen. Zur Stellung von Zwittern in A. WACKB, 'Vom Hermaphroditen zum Transsexuellen. Zur Stellung von Zwittern in
der Rechtsgeschichte, in H. EYrrCH, W. ODERSKY AND F.). SÄCKER (eds.), Festschrift der Rechtsgeschichte', in H. EYRrCH, W. ODERSKY AND F.). SÄCKER (eds.), Festschrift
für Kurt Rebmann zum 65. Geburtstag, C.H. Beck, Murich 1989, pp. 861-903. From an histoxiographical viewpoint, Wacke's remarkably well-documented contribution present the additional interest that it was written before the rapidly developing scientific, doctrinal legislative and broader legal changes related to transsexual and intersexual issues of the last quarter-century had taken place: his historical approach therefore still largely reflects the relatively conventional legal-conceptual framework which prevailed until the end of the 20 th century. 
more complex, for Baldus recites, on the one hand, the line of thinking that the configuration of the sexual organs is decisive, but, on the other, he also presents the argument according to which a person (presumably: whose gender is uncertain) who shows the physical, mental and moral qualities expected from a vassal called to provide military assistance and political counselling (auxilitum et consilium), should be regarded as a man. The latter argument may be seen to take a (feudal) notion of gender into account rather than an anatomical approach to sex. However, the issue of this case is more complicated because there is strong evidence that the version of Baldus' opinion in that consilium (in printed versions, but apparently also in the main manuscript of reference) is truncated or corrupt. Baldus appears to refer to the same case in his lectures on feudal law, where he reports his advice more simply as being in favour of the heir, because it was determined that he was not a woman (and that opinion may have been influenced by the idea that the male sex was deemed to prevail as being stronger). In his lectures on the Code, Baldus also seems to refer to the same case, and provides yet another, somewhat different, argument if the physical defects of the sexual organs are not commonly visible (which is presumably the case when the person is dressed up) and that person's (physical?) aptitudes are those associated with a man, the defective make-up of the sexual organs will not be decisive. Whatever may have been Baldus' actual opinion in his consilium, this case shows the versatility of arguments put forward in late-medieval legal thinking. Although the decision to be reached was necessarily framed in a binary system, which would preclude a stable 'third-gender' categorisation, the reasoning is strongly issue-related, and therefore fact-related, and allows for by-passing the evidence of the genital organs by taking into consideration qualities and inclinations which, in modern terms, come closer to gender identification - both self-identification and social identification. The consilium also includes a brief passage which may suggest that Baldus was prepared to accept, if the difficulty was one of imperfectly formed sexual organs, that a surgical intervention might solve the issue. ${ }^{19}$

19 I have used the editions: BAIDUS DE UbALDIs, Consitia, Venice 1575, vol. 3, Cons. 237, fols. 67v-68r; and Milan 1492-1493, III (no pp. nn. but also Cons. 237); BALDUS DE UBALDTS, Lectura super usibus feudorum, Pavia ca. 1474, $1.6 \$ \mathrm{Mutum}$, fol. 40rV; Bardus DE UBALDIs, In Sextum Codicis Commentaria, Venice 1599, ad C. 6.55 .12$, f. $189 \mathrm{rv}$ (with my gratitude to In Sex. Codch Conith Dr. D. Fedele for providing me with references and print-ouss). On the case, its context and its sources, see J. Krom degli Ualdi sul caso di Giovan Malaspina, in A PALAzzo (ed.), Diritto e processo, AnnLario giuridico dell' Universita degli Studi di Perugia, Perugia 2010, pp. 97-112; F. TREGGiarI Le ossa di Bartolo. Contributo alla storia della tradizione giuridica perugina, Dep. Storia Patria Umbria, Perugia 2009, pp. 39-44; A. WijFrets, 'De hermaphrodisme à l'intersexualité. Dejuridisation, (forthcoming).
Late-medieval and early-modern legal science was nevertheless mostly influenced by three ancient Roman law texts. A first fragment ${ }^{20}$ asks with whom a hermaphrodite should be compared, and the general answer is: one should consider that the hermaphrodite belongs to the sex (or gender? In Latin: sexus) which prevails in a particular individual. The answer indicates that the individual will be regarded (in law, or at least for particular legal issues) either as a woman or as a man.

Another text ${ }^{21}$ addresses the issue of men who cannot easily procreate (a situation which may arise in very different circumstances, e.g. because of old age and impotence), whether they can institute an heir (in Rome, an important feature of one's social and legal status). Specifically, with regard to the case of a hermaphrodite, paragraph 2 states that if the male capacities prevail in a particular individual, that person has the power to do so.

Finally, a short fragment ${ }^{22}$ which says that in order to determine whether a hermaphrodite can witness a testament (a will in Roman law), the determining test is the quality of the sex (again: sexus in Latin) which lights up.

These three fragments highlight two features: first, the mention of 'hermaphrodites' in the authoritative Roman legal texts meant that their existence was admitted in law; secondiy, they would nevertheless not have a status sui generis, but, for specific legal issues, be categorised either as a man or as a woman.

In Iate-medieval and early-modern legal reasoning, such Roman law texts could be used in various contexts, even entirely outside the sphere of personal status. ${ }^{23}$ However, they were generally discussed in their own right in the legal literature of glosses and commentaries. The same texts appear prominently

20 D. 1.5 .10 [Ulpianus ( $\dagger$ c. $223 \mathrm{AD}$ ) libro 1. ad Sabinuma]: 'Quaeritur: hermaphroditum cul comparamus? et magis puto eius sexus aestimandum, qui in eo praevalet'

D. 28.2.6 pr. [Ulpianus Iibro 3. ad Sabinum]: 'Sed est quaesitum, an is, qui generare facile non possit, postumum heredem facere possit, et scribit Cassius et Iavolenus posse: nam et uxorem ducere et adoptare potest, spadonem quoque posse postumum heredem scribere et Labeo et Cassius scribunt; quoniam nec aetas nec sterilitas ei rei impedimento est. $\$ 1$. Sed si castratus sit, Iulianus Proculi opinionem secutus non putat postumento est. $\$ 1$. posse instituere, ouo iure utimur. $\$ 2$. Hermaphroditus plane si in eo virilia pravareden postumum heredem instituere poterit'. D. 22515.1 (Daulus (20d/3rd c. AD)

D. 22.5.15.1 [Paulus (2nd/3rd c. AD) libro 3. sententiarum]: 'Hermaphroditus an ad testamentm adhiberi possit, qualitas sexus incandescentis ostendit'.

23 e.g., in a case of 1605 before the High Court of Admiraity in London, where an advocate was using one of the fragments as an authority in order to argue that a Dutch privateer's man-ofwar which had been mainly equipped and manned by an English crew had nevertheless to be treated, in spite of the Dutch captain and his commissions, as an English ship and therefore as a venture violating the 1604 Anglo-Spanish peace treaty (A. Wispresus, Alberico Gentil and Thomas Crompton - An Encounter between an Academic Jurist and a Forensic Practitioner [Studia Forensia Historica, I], Ius Deco Publications, Leiden 1992 
in Barnabé Brisson's sixteenth-century civil law dictionary, ${ }^{24}$ which includes a substantial entry on hermaphrodites, referring to both legal and non-legal authorities. In any case, here, too, the hermaphrodite can only be envisaged with reference to 'each of either gender'.

\subsection{FRANCE}

In commentaries and law reports, cases of transsexuality and intersexuality may not always be differentiated. Brisson's contemporary Le Caron published in 1579 a collection of consultations steeped in French legal practice. Consultation 54 of Book 10 somewhat cryptically refers to 'a remarkable case. ${ }^{25}$ The case is at first sight not particularly remarkable: in an unspecified place, the local feudal custom excluded women from inheriting when there were also male heirs. In the family involved in this case, the deceased had only left two daughters, and the eldest of the two had inherited the entire feudal estate. Six years later, however, the family history took a new twist: "The younger sister, having reached the age of 14 or 15 , when women start menstruating, felt a male organ coming out of her, forcefully and violently, changing her from a female into a male individual upon which her guardian [not so much as a period to introduce this part of the sentence: someone with uncompromising legal reflexes!] immediately notified the elder sister' - and one can only speculate that this became a case of serious sibling rivalry. Le Caron's consultation was in favour of the younger sibling Charles, formerly Charlotte. The lawyer offers two lines of argumentation. In the first, he refers to medical and historical authorities, which supposedly testified that such a change could happen naturally, and that it was not such an uncommon occurrence. The second line of argumentation follows a legal reasoning. In order to refute the argument that in any case, the gender of the heirs at the time the father had died and when his succession had devolved was to be taken into account, Le Caron claims that in fact, it had been the already existing male nature of the younger sibling which had come out with puberty, and the lawyer insists that his new appearance incorporated all the reproductive organs. Once again, even though in such a case the argument is inevitably mixed up with the patrimonial interests at stake, the whole reasoning is directed at categorising the person either as a man or as a woman.

24 I used the later edition: B[arnabas] BRIssonivs, De verborum quae ad ius civile pertinent significatione opus praestantissimum ... Halae Magdeburgicae, Impensis Orphanotrophei, 1743 , s.v. 'Hermaphroditus', 543-544. The entry also occurs in other legal dictionaries, e.g. (for a much shorter entry) I[ACOBUS] SPIEGEL, Lexicon iuris civilis, Lugduni, Apud Sebastianum Gryphium, 1545, col. 234 .

25 L [outs] Charondas Le Caron, Responses ou decisions du droict françois ... A Paris, Chez Pierre Chevalier, au mont S. Hilaire à la Court dAibret, 1605, fol. 399rv.
A notorious case (also in today's historiography and epistemology) ${ }^{26}$ was that of Marine or Marin Le Marcis, in Rouen (Normandy), during the early years of the seventeenth century. ${ }^{27}$ According to the printed report on the case by Jacques Duval, a Rouen physician, Le Marcis, had been regarded as a female subject until, around the age of 20, Le Marcis started acting (and dressing) as a man, and made arrangements to marry a widow. ${ }^{28}$ In the ensuing litigation, ${ }^{29}$ expert witnesses commissioned to examine Le Marcis declared the defendant to be a woman. Le Marcis was accordingly accused of homosexual acts and scandalous behaviour, convicted and sentenced to the death penalty. On appeal, a larger commission of experts was appointed, among whom Duval. Duval argued that through a tactile examination inside the apparent female sex of Le Marcis, he discovered a penis from which sperm ejaculated. That finding, always following Duval's report, saved Le Marcis' life, who was nonetheless ordered to dress henceforth as a woman and to abstain from marriage with either man or woman until the age of 25. Duval's printed report lead Jean Riolan, a King's physician, to publish two years later, in 1614, a counterblast in which he argued that (as the title-page states) contrary to common opinion, there are no true hermaphrodites. ${ }^{30}$ Riolan had also been an expert in the case, but argued that Le Marcis' penis was in fact an excrescence, an anatomical deformation which could at least be regarded as a mitigating factor for Le Marcis, who could have bona fide believed that the deformation was a penis. The appellate court's reported decision remains ambiguous, though the conflicting opinions of Duval and Riolan seem nonetheless to suggest that, at least as an interim measure, it classified Le Marcis as a woman.

That decision would not be inconsistent with the apprehension of many lawyers, in the light of shifts in the apparent configuration of sexual organs reported in other cases (such as the one mentioned by Le Caron), to make a

26 M. FouvcauzT, Les Anormaux, Seuil, Paris 1999, pp. 62-66 on the case here discussed. For a list of historians who have dealt with the case, see the article mentioned below, n. 27, p. 111, note 2.

27 L. LatBachrzr-OUVRard, 'Imaginaire anatomique, débordements tribadiques et excisions Le Discours sur les hermaphrodits (1614) de Jean Riolan fils', in L'Hermaphrodisme de ia

28 Renaissance aux Lumières, above n. 4, pp. 111-124.

[ACQUES] DUVAI, Des Hermaphrodits, accouchemens des femmes et traitement qui est requis

29 pour les relever en sante et bien elever leurs enfans, Rouen, D. Geuffroy, 1612.

D. BRANCHER, "Le "gente" incertain - De I'hermaphrodisme littéraire et médical," in L'Hermaphrodisme de la Renaissance aux: Lumieres, above n. 4, PF. 307 324. I have not been able to check if any court records on the case are surviving.

J[aAN] Rrolan, Discours sur les Hermaphrodits - Où il est demonstré contre lopinion commune, qu'il n'y a point de vrays Hermaphrodits, A Paris, Chez Pierre Ramiex, 1614; to which the first author replied: J[ACQUES] DUVAI, Response au discours fait par le sieur Riolan docteur en medicine o Professeur en Chirurgie \& Pharmacie a Paris, contre l'Histoire de l'Hermaphrodit de Rouen. A Rouen, Chez Iulian Courant, demeurant au haut de la ruë S. Croix des Pelletiers s.d. [1614]. 
final determination of a person's sexuality when faced with conflicting evidence. A hermaphrodite thus existed at least as an unstable, provisional status, for individuals whose uncertain sex had not been definitively determined as male or female by a court.

By the end of the Ancien Régime, relying on medical opinions and referring to several causes célébres from the remote and recent past, the accepted opinion among French lawyers, for which the expertise of physicians was referred to, was that 'real' intersex persons did not exist. Typically, the entry in Guyot's Répertoire, echoing in some ways the entry in the Encyclopédie, expressed that argument, ${ }^{31}$ referring to several cases, and elaborating on the at the time recent case of Anne Grand-Jean ${ }^{32}$ - but not, characteristically, to any Roman law text or civil law scholarship. It should be noted, however, that the received definition of the 'hermaphrodite' was restrictive: it required the test of combining the full physical reproductive apparatus of both sexes. An individual's sense of gender identity was easily set aside, as in the case of Grand-Jean, by considering that the person may have been deceived by her own defective anatomical make-up. Any decision as regards the attribution of the gender, if the sexual identity was in doubt and challenged the apparent status of the person, was therefore a prerogative of forensic determination.

The case of Giacoma Foroni provides a first-hand documented illustration of the resulting administrative practice during the first years of the nineteenth century, when the administrative machinery of the French state intended to operate on rational and scientific grounds. The uncertainty of Foroni's gender (who had since childhood appeared to be a woman) was raised when she wanted to marry a man. A commission of experts, authorised by the government was charged in 1802 to carry out an investigation in the hamlet where Foroni

31 Répertoire universel et raisonné de jurisprudence civile, criminelle, canonique et bénéficiale [... publié par M. Guyot ...], vol. 8 (A Paris, Chez Visse, 1784), s.v. 'Hermaphrodite', pp. 503-505. The entry was repeated without changes in the edition I have used of Merlin's post-revolutionary Repertoire universel et raisonné de jurisprudence, vol. 13, 5th ed., Chez H. Tarlier, Brussels 1826, pp. 325-326.

32 A person who was at first regarded as a woman, but who developed masculine features and attitudes after puberty, and eventually married as an adult. He was convicted in Iyon in the 1760 s for having violated the sacrament of marriage, but the Paris Parliament overruled the conviction, apparently accepting that the defendant had acted bona fide. Pampots the case and prot the case and proceedings were published at the time, e.g. Reflexions sur les Hermaphrodites, relatwe a d Ane Grand au Parlment [A ANignon, \& se vend a Lyon, Chez Claude jacquenod Als, 1765]; Memoire pour Anne Grand Jean, connu sous le nom de Jean-Baptiste Grand Jean, Accusé $b$ Appellant Contre Monsieur le Procureur General, Accusateur et Intime. Question. Un hermaphrodite qui a épousé une fille, peut-il être réputé profanateur du Sacrement de marriage, quand la nature Grand Yean à François Lambert sa femme [A Paris, De P'Imprimerie de Louis Cellot, 1765]. lived. Members of the commission were four physicians and surgeons of the Medical-Surgical Class of the Academy in Mantova, accompanied by a French commissioner and a professional draughtsman. The extensive report of their commission gives a detailed account of their investigation in situ, their interrogation of Foroni's relatives and others, and of the medical and quasiforensic examination of her body. ${ }^{33}$ The report includes several minute drawings of her anatomy, in particular of her genitals. Here again, although Foroni's attitudes and self-conscience as a woman are discussed, the sexual anatomy appears to be the focus of the determination of an individual's gender. The commission concluded that Foroni, in spite of presenting several features of female organs, and although male organs were not fully developed, had to be categorised as a man. ${ }^{34}$ The detached scientific approach of the commissioners notwithstanding, the report seems to confrrm the underlying opinion that a distinct hermaphrodite category, understood as combining (perfectly) the (physical) features of both sexes, did not exist.

\subsection{GERMANY}

In the Holy Roman Empire, learned legal literature and the practice of higher courts remained on the whole much more strongly influenced by the academic civil law tradition. A book on 'hermaphrodites' by a non-lawyer, Caspar Bauhin, first published in 1600 , includes a compilation of texts from various scholarly works, including (mostly traditional, late-medieval) legal commentaries. ${ }^{35}$ From these, the author borrows a list of legal issues which had occupied legal minds. ${ }^{36}$ Examples of these issues are: Whether a masculine or feminine name should be given at the child's baptism? Can a hermaphrodite marry? Succeed to a copyhold? Be promoted to holy orders? Be a judge? An arbitrator? An advocate? A VC of a university? How should a hermaphrodite serve in any office? Should such a person stand in judgment as a man or as

33 Jaqueline Foroni rendue d̀ son veritable sexe, ou Rapport, Réflexions et jugement présentés à I'Académie de Mantoue, par la Classe de Médecine, sur le sexe d'un individu vivant, connu sous le nom de Jaqueline Foroni [A Milan, De l'Imprimerie Française et Italienne à St. Zeno, An X de la Republique française (1802)].

34 C. SETH, "Entre curiosa et oeuvre scientifique - Le cas Louis Hainaut, Marie Augé et Jacqueline C. SETH, 'Entre curiosa et oeuvre scientifique - Le cas Louis Hainaut, Marie Augé et Jacque
Foroni," in L'Hermaphrodisme de la Renaissance aux. Lumières, above, n. 4, pp. 125 146.

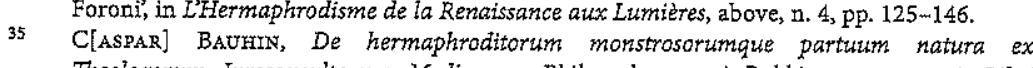
Theologorum, Jureconsultorum, Medicorum, Philosophorum, \& Rabbinorum sententia Libri Duo, [Oppenheimii, Typis Hieronymi Galleri, Aere Johan. Theodori de Bry, 1614; Francofurti, Excudebat Matheus Becker impensis Io. Theo. Io. Israel de Bry, frat., 1620].

36 The list was reproduced in an English translation in a treatise on bermaphrodites published in London one and a half centuries later: J[AMES] PARSONs, A Mechanical and Critical Enquirr into the Nature of Hermaphrodites [London: Printed for J. Walthoe, 17441]. 
a woman? ... These and other questions reflect gender-related discriminations (but in many ways also other discriminations, e.g. between legitimate and illegitimate children) which influenced a person's legal status and social position in public life and in that person's personal and family relations. It shows that in the late-medieval and early-modern legal scholarship tradition from which Bauhin drew his authorities, the lawyers' approach to persons whose gender was not clearly identified as male or female remained very much (not unlike the approach in the Roman law texts) case- and fact-related, bearing in mind the perceived social interests (i.e. also interests of third parties) at stake.

The learned law tradition in Germany and its reliance on Roman law texts is reflected through several theoretical legal works, such as a treatise published in 1692 by Jacob Möllex, in which the author also drew from a wide range of heterogeneous legal and classical sources. ${ }^{37}$ Möller's definition of the hermaphrodite is conventionally that of a person who appears to have the sexual make-up of both female and male genders or none of it. However, he adds that the term is also used for persons whose sexual actions are deemed immoral. ${ }^{38}$ Möller's treatise still expresses a typically traditional approach consisting in accumulating opinions from various authorities, in his case extensively (but not exclusively) from legal authorities.

The issues he discusses match to a great extent those already advanced in Bauhin's summary a century before, though here they are treated in much greater detail. In some cases, policy considerations appear. For example, when the topos of the possibility of a hermaphrodite becoming a university vice-chancellor is raised, the negation in the cases of a person whose male sexuality is not prevalent is explained through a long excursion on the exclusive privilege of masculinity in holding offices of public or corporate governance. In the private sphere, however, such as the baptism name or even marriage, the individual's choice of gender may prevail.

Some eighteenth-century German codifications include provisions on hermaphrodites. This was the case of the Bavarian Civil code of 1756, usually regarded as a conservative codification with respect to the pre-existing state of Bavarian law. A short provision deals with the sex-assignment

37 J[ACOBUSS] MörLgRUs, Discursus duo philologico-juridici, prior De Cornutis, posterior De hermaphroditis, eorumque jure, Uterque Ex Jure Divino, Canonico, Civili, Consuetudinibus Feudorum, variisque Historiarum monumentis, rerumque antiquarum Scriptoribus, private industria, horisotiosis congestus [Francofurti, Typis Christoph. Andreae Zeitleri, 1692].

38 :... qui sexu sunt indistincti, nimirum, qui vel neutrum, vel utrumque habere videntur; licet etiam Hermaphroditus is dicatur, qui turpiter $\&$ facit, et patitur adversus \& versus impudicus,

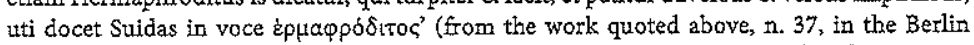
1699. edition, p. 142; the reference at the end of the quote is to the Medieval Byzantine so-called Suidae Lexicon). of hermaphrodites: ${ }^{39}$ the main rule is that experts (i.e. physicians) 40 will determine the person's gender. However, if the evidence is that both sexes appear to be equally present, the person herself/himself will make the decision and have to stand by his or her decision, or be subjected to criminal punishment. The Bavarian statute imposed thus the binary sex-assignment: i.e. that in law, the hermaphrodite would not be recognised as such, but would be identified with a man or woman's legal status.

A few years earlier, in 1749 , at an interim stage of the preparations for the Prussian codification, a draft compilation was published, which also included some general provisions on hermaphrodites. ${ }^{41}$ The relevant section starts by subdividing human beings in men, women and Zwitter (intersex persons). The latter class is defined as persons who have simultaneously the features of both sexes (utrumque). The system anticipates that of the Bavarian Code a few years later: the hermaphrodite must be categorised according to the prevailing sex, either as a man, or as a woman. If the two sexes are equally developed, the individual has a choice, but cannot act later contrary to that choice - if the person does, he or she may be convicted and sentenced to corporal punishment. And if the person has married a man, she (as she is then regarded by the law) cannot marry a woman at a later stage. The degree of self-determination remained therefore limited, and, moreover was subordinated to any determination which a previous enquiry might have made.

The Prussian codification of 1794 represents in many ways the nonrevolutionary accomplishment of statutory evolutions in Germany (here in particular: Prussia) towards the end of the Ancien Régime. The Prussian Code's system on intersex persons differs from the mid-eighteenth-century project. ${ }^{42}$ Again, the lawmaker imposes a choice between male and female gender.

39 Codex Maximilianeus Bavaricus civilis ... [München, Gedruckt von Johann Vötter, 1756], I.3 $\$ 2:$ :... Hermaphroditen warder $2^{\text {do }}$ dem Geschlecht beygezehlt, welches nach Rath und Meinung deren Verständigen vordringt, falls sich aber die Gleichheit hierin bezeigt, sollen sie selbst eins erwählen, und von dem Erwählten sub Paena Falsi nicht abweichen'

40 During the late 18th century and early 19th century, professional (and academically During the late 18 th century and early 19 th century, professional (and academically
educated) medics succeeded in barring other professional groups (in particular, midwives) whose expertise on matters of sex determination had traditionally been acknowledged (U. KLöPPRL, XXOXY ungelöst - Hermaphroditismus, Sex und Gender in der deutschen Medizin - Eine historische Studie zur Intersexualität, Transcript Verlag, Bielefeld 2010, pp. 211-215).

41 Project des Corporis Juris Fridericiani das ist Gr. Königl. Majestät in Preussen in der Vernunft und Landes-Verfassungen gegrü̈ndete Land-Recht worinn das Römische Recht in eine natürliche Ordnung, und richtiges Systema, nach denen dreyen Objectis Juris gebracht ... [Halle, In Verlegung des Waysenhauses, 1749], Part I, Book I, Titie IV, \$3.

42 I have used: Allgemeines Landrecht für die Preußischen Staaten von 1794. Mit einer Einführung von Dr. Hans Hattenhauer und einer Bibliographie von Dr.Günther Bernert, Dritte, erweiterte Auflage, Luchterhand Verlag, Berlin 1996, \$\$19-23, p. 61. 
The original choice is left to the parents. Then, once the person has reached the age of 18 , he or she can determine his or her gender - which implies the possibility of a different choice from the parents. The individual's own choice is binding for the future. However, when the interests of third parties are at stake, an investigation by experts can be ordered at the request of the latter. The experts' determination prevails over any choice expressed by the parents or the individual. In practice, that system entailed that in any case, a gender determination took place, and that as soon as the gender was relevant in social relations (status, inheritance, marriage, contracts, property, proceedings ...) the case was deferred to experts (probably, increasingly the exclusive preserve of graduated and established medics), whose opinion was decisive.

In the course of the nineteenth century, commentators of the Prussian law paid little attention to the provisions on sex-determination. ${ }^{43}$ The binary system of reference ${ }^{44}$ became even more important, as, by the second half of the century, commentators would routinely refer to medical opinions denying the

While preparing this chapter, I was able to consult a sample of such commentaries, including E.F. KIEn, System des Preußischen Civilechts ... unter Benutzung der neusten Rechtsquellen E.F. KLEL, System des Preujuschen Civirechts ... Lnter Benutzung der neusten Rechtsquellen und mit Finverweisung auf das gemeine Recht, Erster Band, In der Buchhandlung des Waisenhauses, Halle 1830, p. 66; J.F. THöNE, Fundamental-Lehren des Preußischen Privatrechts, einschließlich der Abfassungsgeschichte des Allgemeinen Landrechts und der Lehr von dem Besitz und der Verjährung, Erster Band, in der Hahn'schen Verlags-Buchhandlung Leipzig 1833, p. 283; J.A.L. FÜRSTENTHAL, Das Preußische Civil-Recht nach Anleitung und der Titelfolge des Allgemeinen Landrechts, mit Berücksichtigung der neueren Gesetze, der Doktrin der Praxis und des Römischen Rechts, Bei Theodor Theile, Körigsberg 1842, p. 34; C.I. Kock Lehrbuch des Preußischen gemeinen Privatrechts, Zweite verbesserte und vermehrte Auflage, 1. Band, Verlag von $T$. Trautwein'schen Buch und Musik-Handlung, Berlin 1851, p. 151 C.C.E. Hyersemenzei, Vergleichende Uebersicht des heutigen Römischen und Preußischen gemeinen Privatrechts, Erster Theil, Verlag von Gustav Hempel, Berlin 1852, p. 91, L.E. HeydemanN, Einleitung in das System des Preußischen Civilrechts, Erster Band.Allgemeiner Theil, Verlag von Beit und Comp, Leipzig 1861, p. 132; [C.J. Kocr] Allgemeines Landrech für die Preußischen Staaten. Unter Andeutung der obsoleten oder aufgehobenen Vorschriffen und Einschaltung der jüngeren noch geltenden Bestimmungen herausgeben mit Kommenta ind Einschaltung der jungeren noch gettenden. Bestimmungen, herausgeben mit Kommentar D. Collin) Ben D. Colln), Berlo 1374, Rücksicht auf dic Rechsesetzgebung, das gemene Recht und den gemeinrechtlichen Prozeß, rister Band, Velagvon preuj3ischen Privatrechts, Verlag von J. Guttentag (D. Collin), Berlin und Leipzig 1887, p. 50 note 3; H. DeRNBURG, Lehrbuch des Preußischen Privatrechts und der Privatrechtsnormen des Reichs - Erster Band: Die Allgemeinen Lehren und das Sachenrecht des Privatrechts PreußBen und des Reichs, Fünfte, neubearbeitete Auflage, Verlag der Buchhandlung des Waisenhauses, Halle a.S. 1894, p. 96, note 8; comp. idem, Lehrbuch des Preußischen Privatrechts und der Privatrechtsnormen des Reichs - Erster Band, Zweite, neubearbeitete Auflage, Verlag de Buchhandlung des Waisenhauses, Halle a.S. 1879, p. 93 note 8.

4 See also in that sense the brief statement (referring to Roman-Catholic canon law doctrine) by E. BARTeLs, Ehe und Verlöbnis nach gemeinem und partikulärem Rechte in der Provin Hannover, Hahn'sche Hofbuchhandlung, Hannover 1871, pp. 94-95. existence of hermaphrodism. ${ }^{45} \mathrm{~A}$ standard phrase in legal literature was that the paragraphs of the Prussian code on Zwitter were 'unpractical'. 46

That general attitude among legal writers may partly explain why no provisions on hermaphrodites were included in the Bürgerliches Gesetzbuch (BGB, the German Civil Code) of 1896. At the risk of simplifying the comparison between France and Germany, it would seem that the medical-scientific approach which tended to deny the existence of intersexuality (largely reduced to the full constitution of reproductive organs) had become, partly for ideological reasons, mainstream thinking among French jurists by the end of the eighteenth century, and from the early nineteenth-century onwards among German legal scholars. However, that perception may have to be qualified or revised in the light of more recent studies of the changing medical approaches in the course of the nineteenth century. Thus, whereas A. Dreger argued that from the later nineteenth century onwards, medical science tended to identify the gonads as the determining organs for identifying the sex of a person and to dismiss on that basis sexual ambivalence and hermaphrodism, ${ }^{47} \mathrm{U}$. Klopppel found that the medical literature started focusing on gonads from the early nineteenth century onwards, moved by concerns about demography and eugenics. ${ }^{48}$ The relatively early interest for gonads as the test of a person's sexuality, Klöppel suggests, was linked to growing medical concern in establishing a person's procreative capacity. That, in turn, may account for a growing interest - which could in many instances not be satisfied on technical grounds - in examining the internal reproductive organs.

Klöppel's research on the development of medical approaches to intersex (in particular, in German medical literature) throughout the nineteenth century gainsays the German jurists' dismissal of the statutory provisions on hermaphrodites on the grounds that medical science denied their existence. On the contrary, medical scientists sought new criteria for establishing and explaining sexual differentiation, and though the binary distinction between male and female remained the fundamental reference, these two categories were now increasingly situated as the poles of continuous and gradual scales of differentiation between them. Moreover, the medical profession was concerned with both the theoretical coherence of the new criteria put forward, and the

45 [C.J. Kocв] Allgemeines Landrecht für die Preußischen Staaten (above, n 43), p. 76, note 20: .. Die Aerzte behaupten, daß es eine wahre Zwitterbildung nach Theorie und Erfahrung nicht gebe' (with a reference to L.J.C. MeNDE, Ausführliches Handbuch der Gerichtilichen Medizins); see also the quote from Joseph Schmidt's manual, above $n, 43$.

46 Frscher, above, n. 43, p. 50, note 3: 'Die ganz unpraktischen Bestimmungen über $Z$ witter'; ScHMIDT, above n. 43, p. 68: 'Die neuere medicinische Wissenschaft verwirtt entschieden die Existenz der Zwitter. Die \$\$19-23, Tit. I, sind daher unpraktisch geworden?

47 A. DREGER, Hermaphrodites and the medical invention of sex, Harvard University Press, Cambridge (Mass.) 2003

48 Kröppgi, above n. 40, pp. 217-218 and 268-269; the argument mentioned here above is also developed in her article 'The lost innocence of hermaphrodites', in L'Hermaphrodisme de Ia Renaissance aux Lumières, above n. 4, pp. 147-168. 
practical relevance of scientific progress. For example, because the reliance on gonads as the decisive test for differentiating male from female could in many instances only be established post-mortem, the test was impractical for physicians who were called to advise the authorities or courts on an individual's sex assignment or determination for birth registration or establishing the person's capacity to marry (or to perform reproductive sexual acts as husband or wife). It seems therefore that such practical necessities may have contributed to convince many practitioners to consider other factors, which in their own way were also referred in scientific debates challenging the exclusive reliance on gonads as the decisive test: other anatomical and physical features than the genitalia, but also mental disposition and even sexual orientation could be taken in consideration alongside or in lieu of gonads. The broadening of the factors and tests in turn revived a debate between the respective role of 'innate' and 'acquired' factors which determined one's sexuality. For scientists, hermaphroditism was sometimes viewed as an observable testimony of their theories. At the same time, the scientific discussion was often intertwined with moral and political issues. In general, attempts at systematisation were prone to be affected by hierarchical representations. Theories which emphasised the developing stages of sexual differentiation from an 'original' cell (which was alternatively presented as sexually indifferent or female) would imply that hermaphroditism was linked to underdeveloped or pathologically developed creatures, and thus inferior to the stage of perfect differentiation, while some nineteenth-century medical theorists would award masculinity a higher position in the 'natural order' than femininity. Early nineteenth century proposals by some lawyers to abolish a separate status for Zwitter and to delegate the determination of the sex to medical experts therefore ignored the relevance of hermaphroditism in contemporary medical-scientific debates. Nevertheless, when under imperial rule, an Act was passed (6 February 1875) establishing birth, marriage and death registers, it only provided for the mention of either the male or female sex in the birth register; medical authorities were critical of the suppression of the possibility of leaving the possibility in law to recognise 'real' hermaphrodites, who could either combine essential features of both man and woman, or neither. A practical manual for officials in charge of birth registers included a sample form for cases where the medical experts had not (yet) been able to determine the sex of the child, but this appears to have been a rare acknowledgement of the medical approach in (quasi-)legal literature at the time. However, as the $B G B$ ignored intersex persons, its implementation reinforced the requirement to determine the sex of an individual as male or female - any legal uncertainty could only be temporary and was to be cleared by medical professionals. ${ }^{49}$

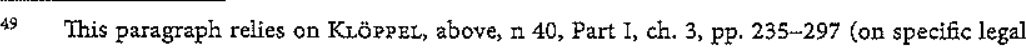
issues in the light of medical developments: pp. 273-276 (19th century and Weimar Republic) and 551-554 (after the Second World War).

\section{AN AGE OF CHANGE (LATE TWENTIETH CENTURY AND EARLY TWENTY-FIRST CENTURY)}

From the late nineteenth century onwards, and during the twentieth century, the anthropology underpinning Western sciences, humanities, social relations and cultural representations changed fundamentally. Gender identity and the principle itself of gender identity - was thoroughly challenged. The distinctiveness of intersex issues notwithstanding, the relatively recent tendency towards ensuring a systematic protection of intersex persons against discrimination needs to be seen against the long-term background, during the twentieth century, of women's emancipation, gay rights movements and nondiscrimination of transsexuals: all areas in which categories of persons had long been discriminated against, whereby the legal discriminations were based on multi-secular cultural biases against self-determination of gencer identity and sexual relationships. A growing number of scientists, not only in the human and social sciences, have contributed in scholarly publications to undermine conventional conceptions about the differentiation between genders, or about the definition of gender identity. Again, their research and publications have received a great deal of press coverage, contributing to a revision of social and cultural attitudes on sexual issues, ranging from sexual orientation to gender identity of inter- and transsexuals. By the beginning of the twenty-first century, at least in Western societies, the traditional gender differentiation has not only been increasingly eroded in mainstream cultural attitudes, ${ }^{50}$ in the social sciences and other areas of scholarship, it has also affected areas of the law where gender differentiation seemed at first firmly established. For example, two areas where the law has been challenged on issues which until recently were commonly believed to be beyond the outer limits of legal protection against discrimination are the admission of women to combat units (in regular armies) and the status of transsexuals in sport competitions. (Both issues could be extended with regard to their application to intersex individuals.)

Gender issues of transsexuality and intersexuality have by now largely been recognised as human rights-related issues. ${ }^{51}$ Indeed, during the last decades

50 Yet, apparently new artistic expressions of these attitudes have sometimes an ancient analogy: as, e.g., in the film adaptation of David Mitchell's novel Cloud Atlas, released in the US in 2012 and early 2013 in Europe. The directors, one of whom was at the time a transgender artist (and her brother has since then, become her sister), have playfully integrated and renewed the old tradition of transsexuality in stage-playing by casting the same actors in different roles representing different genders. The novelty of our age, it seems, is that such devices are now reflecting a much broader popular acceptance and culture in Western societies.

51 That development is now widely perceived among various and culture in Western societies. That development is now widely perceived among various actors militating in favour of Cone io one] interser - Das Zwei-Geschiechter-System ats Menschenrechtsue 1-0-1 $\mathrm{Hg}$. Von der Neuen Gesellschaft für Bildende Kunst, Berlin 2005, includes a variegated 
of the twentieth century, the emancipation of women, of gays, lesbians and bisexuals, transsexuals and intersex persons has been fortified by the development of human rights in all walks of life as a form of effective political, social, economic and cultural enfranchising of formerly discriminated categories of persons - because of gender-related issues or otherwise. That development has also provided an opening, especially in Western societies, for developing a non-discriminatory legal protection and status for intergender persons. Human rights, however, should not be seen historically as irreversible. As political populism, religious fundamentalism; and in general discriminatory social attitudes may revive, human rights will be and are already being challenged, and the most vulnerable groups and minorities may be the first to suffer from such reversals. That is, as things now stand, perhaps one of the strongest arguments for pursuing the human rights developments of the past few decades, not least on gender issues.

selection of contributions by artists, social scientists, historians ... on current issues selection of coltibutions by atists social scientists, ( The essay,

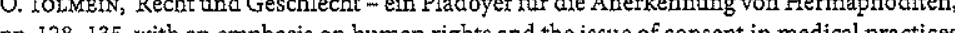
pp. 128-135, wh an emphasis on human rights and the issue of consent in medcal practices tending to re-categorise young persons displaying intersex characteristics. Human rights also

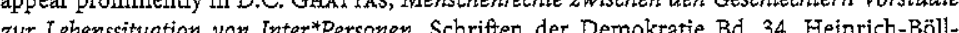
Stiftung, Berlin 2013 